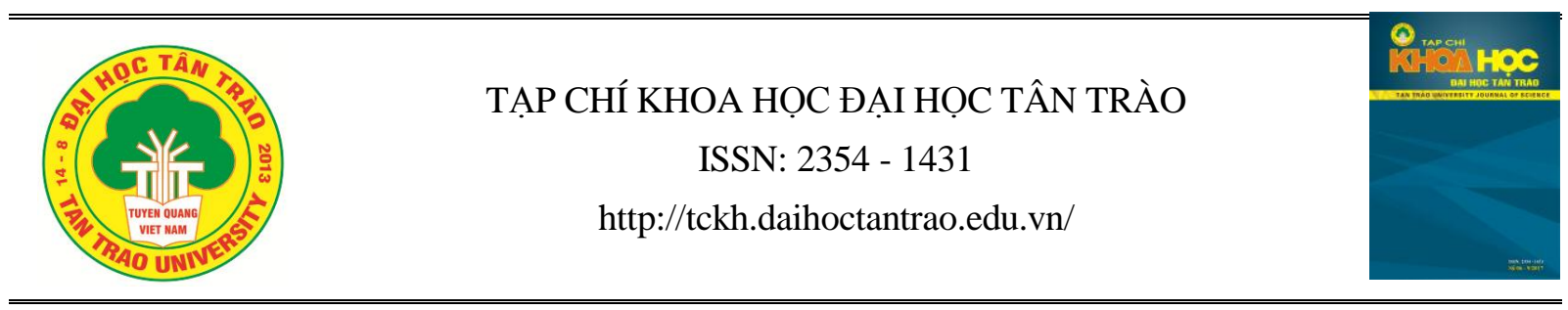

\title{
Fish inventory and fishing practices in Candaba swamp, Philippines: their implication to fishermen's income
}

\author{
Alfred R. Mallari ${ }^{a^{*}}$, Jacqueline V. Bagunu ${ }^{a}$, Gerald M. Salas ${ }^{a}$ \\ ${ }^{a}$ Pampanga State Agricultural University, Philippines
}

\section{Article info}

Recieved:

28/11/2019

Accepted:

$10 / 3 / 2020$

Keywords:

Fish inventory;

fishing practices;

fishing gear;

"Panti"

\begin{abstract}
This study generally aimed to make an inventory of fishes in Candaba Swamp and documented the fishing practices of the local fishermen as they are related to their income. The study documented 14 different species of fishes, each representing 14 families in the Barangays of San Agustin and Dukma Paralaya. The fourteen species were the Elopshawaiensis, Glossobiusgiurus, Megalops cyprinoides ${ }_{2}$ Cyprinuscarpio, Trichopodus pectoralis, Clariasbatrachus, Hypostomus plecostomus, Arius dispar, Hypophthalmichthys molitrix, Anabas testudineus, Carassiuscarasius, Labeorohita, Hypophthalmichthysnobilis, Oreochromis niloticus.
\end{abstract}

The Inventory recorded the Tilapia,Common Carp and Hito species as the most dominant species in Candaba Swamp. Fishermen's ages were between 20 to 89, most of them were between 50-59, used the "panti" (kitig) as fishing gear and with daily income ranging from 100 pesos to 1,500 pesos. The total income of the fisherman during the wet season is from 1,000 pesos to 10,000 pesos, and the daily expenses in each fishing trip is from 20 pesos to 100 pesos which is mostly used for gasoline.

The fishermen's income depended on the number of fishes they catch which was affected by changes in season. The Cost-Benefit-Analysis showed a net income Of P281.27 per day with a Return of Investment of $174.4 \%$.

\section{Introduction}

Candaba Swamp, popularly known as "Pinac," is one of the most panoramic wetland here in our country situated in Candaba, Pampanga, Central Luzon, Philippines. Aside from being the location of one of the oldest settlements in Central Luzon, it is a famous site because of its diverse and multiform fauna and flora and its exotic ecosystem. Candaba swamp is known in the province of Bulacan and Pampanga because of its importance in agriculture, fisheries production, irrigation and its helps in retention of natural flood in the said province here in the Philippines. Tourism in the area has increased, especially during the migratory season, benefiting the LGUs, the communities, and the migratory birds themselves (Torres et al. 2008).

Presently, the swamp is utilized all throughout the year. During summer which is every January to May, the swamp is primarily used for rice and watermelon production. From June to December which is usually the rainy season, the swamp serves as a fishing ground and stopover of migratory birds from Siberia and China. (Melendres, 2014).

Studies in Candaba Swamp were undertaken on the different species of fishes (Bautista \& Barila, 2013); Heavy metal analysis (Kabigting, 2013); Cytogenetic Studies of The waters (Dela Cruz, Ruel, 2012); and 
Mollusk Taxonomy (Mallari and Bagunu, 2013). Literatures in fish biodiversity in the area are very limited, and even, non-reported nor published.

This study is important in providing data on fish inventory in the San Agustin and Dukma Paralaya barangays in Candaba Swamp, Pampanga.The implications of this inventory to the income of the fishermen will also be useful as basis for policy recommendation in the area. This may also serve as a reference material to those who want to know how Candaba Swamp is very important to the livelihood of fishermen in the barangay of San Agustin and Dukma Paralaya. It will also contribute further to the existing knowledge in academic and research endeavors with regard to Biodiversity conservation.

\section{Methodology}

\subsection{Research Design}

The study made use of the descriptive-survey method of research using an interview guide. The identification of the species made use of existing literatures based on their morphological characteristics. The identity and classification were validated by fishexperts from the University of the Philippines, Los Banos.

\subsection{Research Procedures}

\subsubsection{Key informant interview}

Interviews were conducted among the fishermen to elicit their fishing practices. Stratified method was used in determining the sample respondents and in the collection of data thru the survey given to the fishermen in the Candaba swamp. Thirty Percent (30\%) of the total population of 519 fishermen served as respondents of the study.

\subsubsection{Collection of Specimen}

Collection of fish species in Candaba Swamp were based on the total number of fishes captured by the local fishermen. One sample each species group was collected to represent each group and was preserved using Taxidermy procedures for future documentation, identification and deposited at The Biology Museum of the College of Arts and Sciences, Pampanga State Agricultural University, Magalang, Pampanga.

\subsubsection{Identification Procedure}

Identification of fish species in Candaba Swamp was done with the help of a fish expert from UP Los Banos. The species was laid on a flat surface with a ruler below for documentation and measurement. The fins were stretched to determine the number and then the scales of each specimen were also counted.

\subsubsection{Ecological Factors}

The researcher used an YSI Multi Parameter Test Probe and Hach Ammonia Test Kit from the Bureau of Fisheries and Aquatic Resources (BFAR) to determine the environmental factors such a $\mathrm{pH}$, Temperature, Conductivity, Salinity, Turbidity, Dissolved Oxygen and Depth.

2.2.5. Diversity Index and Statistical Analysis of Data

The Shannon-Weiner Index to determine species diversity was used with the following formula.

Shannon- Weiner Index

$\mathrm{H}=\sum[(\mathrm{Pi}) \times \operatorname{In}(\mathrm{Pi})]$

Where:

$\mathrm{Pi}=$ Proportion of Total

Sample represented by species

$\mathrm{S}=$ Number of species (Species richness)

$\mathrm{E}=$ Evenness $=\frac{\mathrm{H}}{\mathrm{Hmax}}$

$\operatorname{Hmax}=\operatorname{In}(\mathrm{S})=$ maximum diversity possible

Simple statistics such as frequency count and percentage was used to analyze the data from the questionnaire.

The Cost Benefit Analysis (CBA) and Return of Investment (ROI) were computed. The formula as follows:

$$
\begin{aligned}
& \text { CBA }=\text { Sales }- \text { Expenses }=\text { Net Income } \\
& \text { ROI }=\frac{\text { Net } \text { Profit }}{\text { Cost of Investment }} \quad X 100 \%
\end{aligned}
$$

\section{Results and discussions}

\subsection{Inventory of fishes in the Candaba Swamp}

There were Fourteen (14) species identified and classified in Candaba Swamp. Among the 14 fish species, 5 of them are Cyprinidae (Common carp, Katkat,Pararak,Roho, and Tie fish) and the other 10 species are from different fish families, the Chanidae, Elopidae, Gobiidae, Osphronemidae, Clariidae, Loricariidae, Ariidae, Terapontidae, Anabantidae, and Cichlidae. In terms of their Genus,two of them have the same genus which is Hypophthalmichthys (Katkat and Tie fish) and the others are from Elops, Glossobius, Megalops, Cyprinus, Trichopodus, Clarias, Hypostomus, Arius, Anabas, Carrassius, Labeo, and lastly Oreochromis (Table 1).

Table 1. Fish species collected in Candaba Swamp 


\begin{tabular}{|l|l|l|l|}
\hline \multicolumn{1}{|c|}{ Family } & \multicolumn{1}{|c|}{ Genus } & \multicolumn{1}{c|}{ Scientific Name } & \multicolumn{1}{c|}{$\begin{array}{c}\text { Common } \\
\text { Name }\end{array}$} \\
\hline Elopidae & Elops & $\underline{\text { Elops hawaiensis }}$ & Bidbid \\
\hline Gobiidae & Glossobius & $\underline{\text { Glossobius gimus }}$ & Biya \\
\hline Megalopidae & Megalops & Megalops cyprinoides & Buan Buan \\
\hline Cyprinidae & Cyprinus & $\underline{\text { Cyprimus carpio }}$ & Common Carp \\
\hline Osphronemidae & Trichopodus & $\underline{\text { Trichopodus pectoralis }}$ & Gurami \\
\hline Clariidae & Clarias & $\underline{\text { Clarias batrachus }}$ & Hito \\
\hline Loricariidae & Hypostomus & Hypostomus Plecostomus & Janitor fish \\
\hline Ariidae & Arius & $\underline{\text { Arius dispar }}$ & Kanduli \\
\hline Cyprinidae & Hypophthalmichthys & $\underline{\text { Hypophthalmichthys molitrix }}$ & Katkat \\
\hline Anabantidae & Anabas & $\underline{\text { Anabas testudineus }}$ & Liwalu \\
\hline Cyprinidae & Carassius & $\underline{\text { Carassius carassius }}$ & Pararak \\
\hline Cyprinidae & Labeo & $\underline{\text { Labeo rohita }}$ & Roho \\
\hline Cyprinidae & Hypophthalmichthys & $\underline{\text { Hypophrhalmichthysmichthys }}$ & Tie fish \\
& & $\underline{\text { nobilis }}$ & \\
\hline Cichlidae & Oreochromis & $\underline{\text { Oreochromis niloticus }}$ & Tilapia \\
\hline
\end{tabular}

3.2. Socio-demographic and fishing practices of the fishermen - respondents

\subsubsection{Socio-Demographic Profile of The} Fishermen-Respondents

\subsubsection{Age of Fishermen-Respondents}

Figure 1 displays the ages of fishermen in Candaba, Swamp. The highest percentage (28\%) of age is found within 50-59 age brockets and the lowest percentage (2.6\%) is found in the 80-89 age brocket. Majority of the fishermen is from 50 to 50 of age because this are the person who did not finish High school to find a decent job , and the lowest percentage are from 80 years and above because they are too old to have a job for their family.

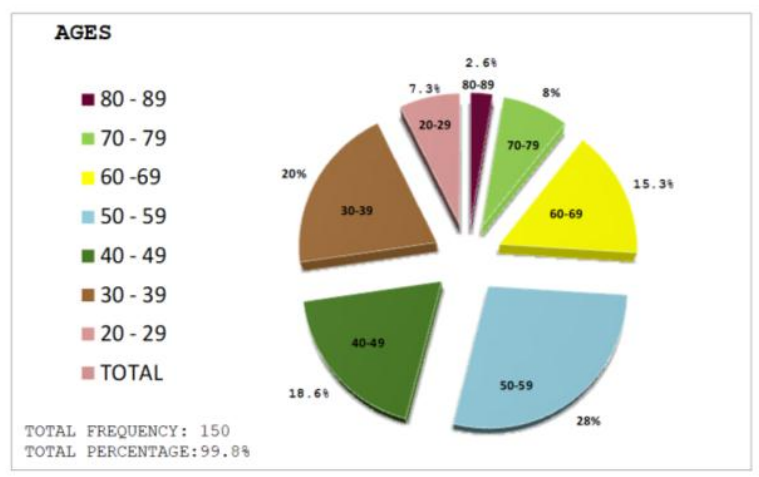

Figure 1. Distributions of Respondents according to age

\subsubsection{Livelihood of Fishermen-Respondent}

As shown in Figure 2, the livelihood of the fishermen is farming comprising $22 \%$, second is construction with $8 \%$, third is vendor with $4.6 \%$, fourth is a truck driver with $3.3 \%$, and fifth is otherswith $2.6 \%$ and lastly, the barangay tanod with $0.6 \%$ then the $58.6 \%$ are just fishermen and no other livelihood.

Majority are fishermen because it is a common knowledge that Candaba swamp during the wet season is a favored environment for fishing because of the retention of natural flood in the said area. This justify why fishing of freshwater fishes is one of the source of income of the people in Candaba swamp.

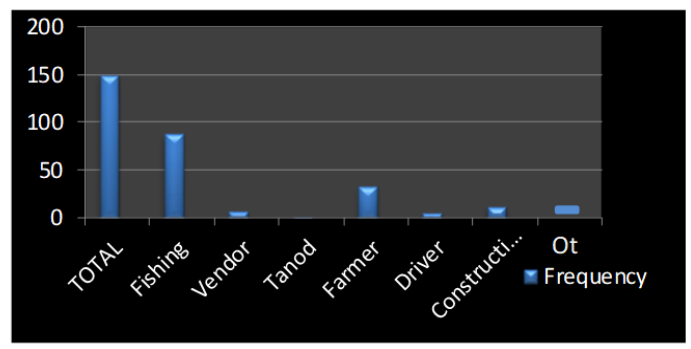

Figure 2.Presents alternative sources of income aside from fishing

\subsubsection{Fishing Practices of the Fishermen}

\subsubsection{Fishing time of Respondents}

As shown in Figure 3, most respondents (41.3\%) have fishing time starting at around 2:01 to 4:00 in the morning. Thirty two percent starts at 4:01 to 6:00 in the morning, thirdly, $14 \%$ fish between 12:00 to 2:00 in the morning the rest starts between 6:00 in the morning to 12:00 noon.

The table shows that more fishermen start fishing very early in the morning because they believe that if they fish early in the morning they have the possibility to catch more fishes to be sold in the market.

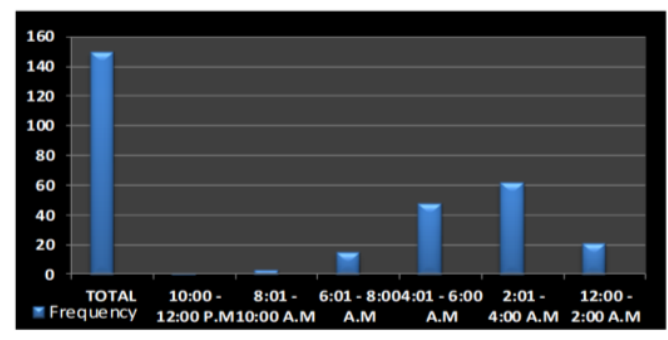

Figure 3. Fishing time of the Respondents

\subsubsection{Fishing duration of fishermen}

As shown in Figure 4, most fishermen have fishing duration within 4-6 hours. This was followed by $26.6 \%$ of the fishermen second for 7-10 hours; 1-3 with a 19.3 percent; and lastly 11 hours and more with a 12.6 percent of the respondents.

Most of the fishermen spend 4 hours, at least, in swamps so that they could capture more. 


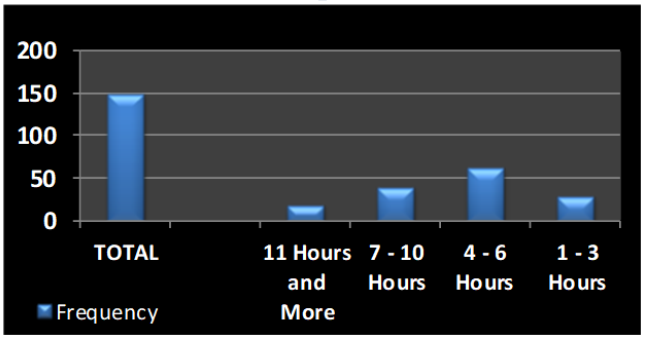

Figure 4. Number of hours spent for fishing

\subsubsection{Fishing Gear used by Fishermen}

Most of the fishermen used the fishinggear Pantiwith the highest percentage of 43.3 percent. For one thing, it catches more fish as compared to lambat and other fishing gears. Panti is easy to repair by hand once it gets broken. Lastly, it is more convenient to use because fishermen set the panti or kitig in swamps and wait until the gear catch a fish.

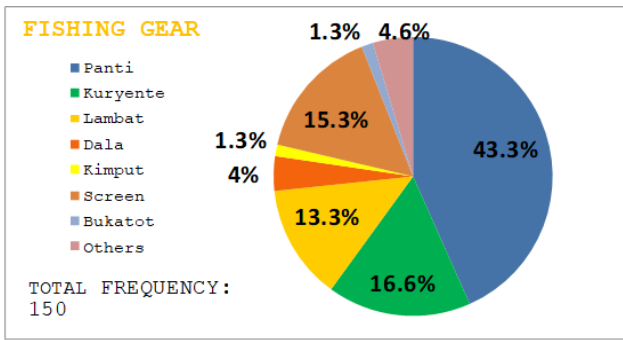

Figure 5. Fishing gear that being used by the Respondents

\subsubsection{Fish Catch and Price Per Kilogram}

As shown in Table 2, the most abundant fish species caught by the fishermen is Tilapia with the average frequency of 58 and 702 kilogram, number 2 is Common carp with the average frequency of 44 and with a 744 kilogram, and the number 3 with an average frequency of 27 with a 187 kilogram.

The fishermen caught Tilapia more than the Common carp and Hito. The Common carp is a lot heavier than the Tilapia, because common carp fishes are bigger in size.But when it comes to the price, fishermen have higher income from Tilapia because it is more expensive than the common carp and hito though hito commands higher price than the common carp.
Table 2. Fish Catch and price per kilogram

\begin{tabular}{|l|c|c|c|c|c|c|}
\hline Fish species & Frequency & Rank & $\begin{array}{c}\text { Average } \\
\text { catch } \\
\text { (kg) }\end{array}$ & Rank & $\begin{array}{c}\text { Total } \\
\text { amount } \\
\text { if sold }\end{array}$ & Rank \\
\hline Common Carp & 44 & 2 & $\mathbf{7 4 2}$ & $\mathbf{1}$ & $\mathbf{1 , 0 0 2}$ & $\mathbf{3}$ \\
\hline Gurami & 10 & 4 & 82 & 4 & 490 & 5 \\
\hline Hito & 27 & 3 & 187 & 3 & 1,720 & $\mathbf{2}$ \\
\hline Kanduli & 2 & 7 & 7 & 8.5 & 120 & 6 \\
\hline Likahuk & 4 & 5 & 30 & 5 & 530 & 4 \\
\hline Pararak & 3 & 6 & 15 & 6.5 & 45 & 7 \\
\hline Roho & 1 & 8.5 & 15 & 6.5 & 5 & 9 \\
\hline Tie fish & 1 & 8.5 & 7 & 8.5 & 10 & 8 \\
\hline
\end{tabular}

\subsubsection{Use of Harvest}

Figure 5, showed how the fishermen used their harvest. Ninety six (96) percent sold their harvest, and three (3) percent use them for food consumption and sold in market, and 2 percent used their harvest for food consumption only.

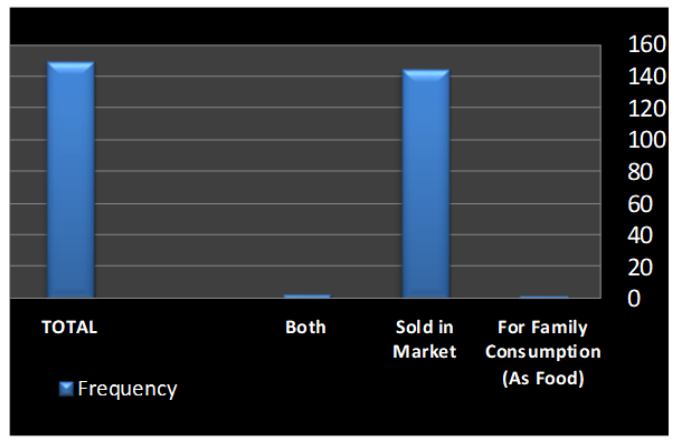

Figure 6. How the harvest used by the respondents

\subsubsection{Harvest Seller}

Figure 7, shows who sells the harvest, The family members such as their spouses and also their children got the highest percentage of 79.3 percent, while the fishermen has a 20 percent and lastly friend with a 0.6 percent.

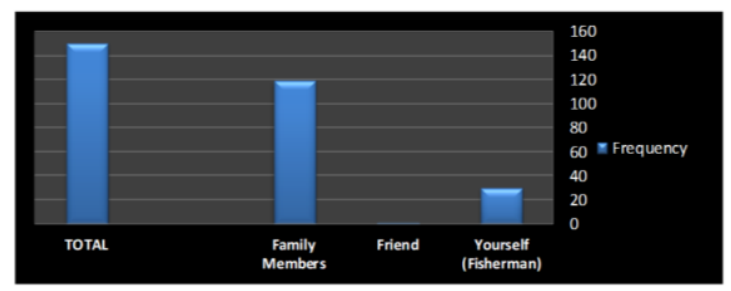

Figure 7. Harvest Sellers

3.2.2.7. Income of the Fishermen During Wet Season

Figure 7 shows the income per day of the fishermen most of them has an income of 100 to 1,500 pesos in daily fishing. The Total income during wet season is 73.3 percent the range of their income starts from 1,000 to 10,000 pesos during wet, 20.6 percent starts for 
10,001 to 20,000 pesos and some of them are 20,001 and above. Then the Total expenses per day of the fishermen 68.6 percent has the daily expenses of 20 to 100 pesos, 17.3 percent has the daily expenses from 101 to 200 pesos, 8 percent has no daily expenses, 2.6 percent from 201 to 300 pesos, 2 pecent from 301 to 400 pesos, 0.6 percent from the 401 to 500 pesos same with 601 to 700 pesos.
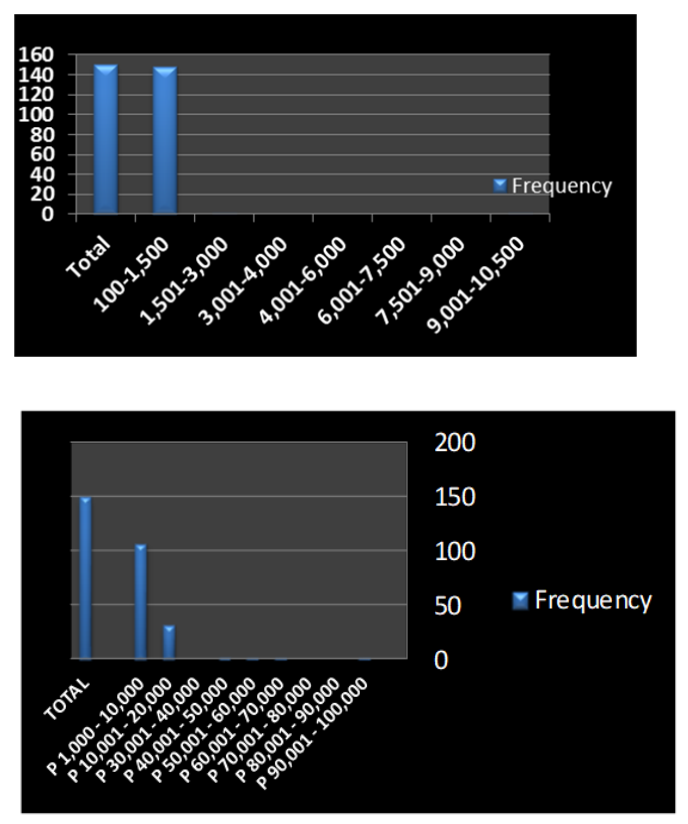

Daily income total income [during weseas

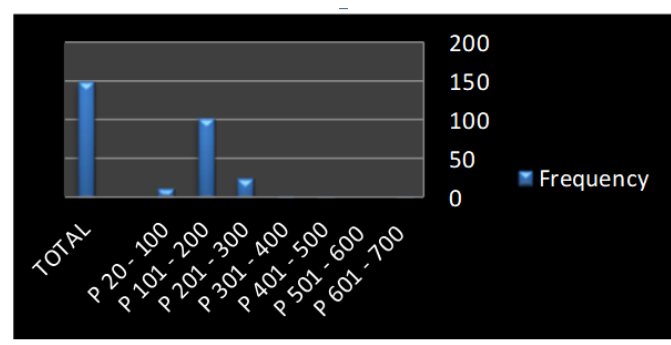

Total expenses per day during wet season]

Figure 8. The Daily Income, Total Income and the Total Expenses each fishing trip of the fishermen during Wet season.

\subsubsection{Perception of Fishermen on their income}

Shown inFigure8 is the sufficiency of the income of the fishermen for their family. Most of them answered the 2 or less sufficient with the 40 percent, while in the 3 or sufficient has a 35.3 percent, in 1 or not sufficient has a 18.6 percent, 4 or very sufficient with a 6 percent and lastly 5 or more sufficient has 0 percent because there's no fishermen answered that their income is more sufficient for their family.

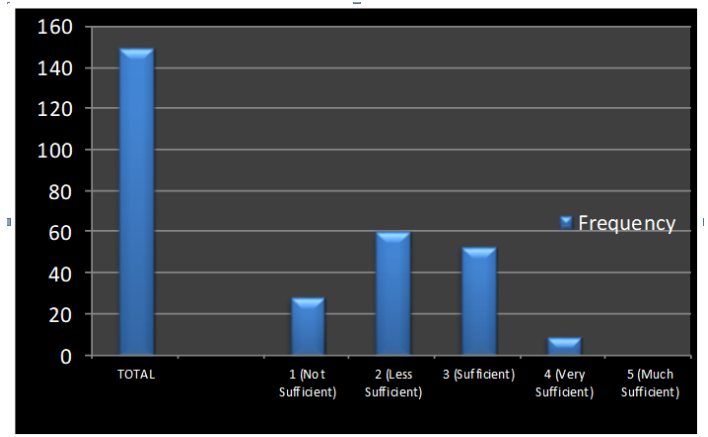

Figure 8. Fishermen's perceptions on the sufficiency of income

3.2.2.9. Cost-Benefit Analysis (CBA) \& Return of Investment (ROI)

Table 3 shows the Average Net Income per Day of the local fishermen of Candaba Swamp, Pampanga. It consists their Sales which is the Average sales of the fishermen is 442.90 pesos if the fishes is sold in the market. While in their Daily Average Expenses which is 161.63 pesos it consists the Gasoline for fishing, Food, and other Daily needs of their family each day, and lastly the Average Net Income of the individual fishermen is 281.27 pesos which is qualified to the Daily Minimum Wage of an individual person. According to National Wages and Productivity Commission from the Department of Labor and Employment the minimum wage in Region 3 starts from 274 pesos to 400 pesos (NWPC-DOLE, 2018).

Table 3. Cost-Benefit Analysis

\begin{tabular}{|l|c|}
\hline \multicolumn{2}{|l|}{ Average Net Income Per Day } \\
\hline Sales & 442.90 \\
\hline Less: Expenses & 161.63 \\
\hline Net Income & 281.27 \\
\hline
\end{tabular}

ROI (Return on Investment)

$=($ Net Profit $/$ Cost of Investment $) \times 100$

$$
\begin{aligned}
& R O I=\frac{281.27}{161.27} \quad X 100 \\
& =174.4
\end{aligned}
$$

\section{Summary, conclusion, recommendation}

\subsection{Summary of Findings}

Based on the data gathered, the researcher came up with the following findings:

4.1.1. There were fourteen species of fishes collected in the barangay of San Agustin and Dukma Paralaya. 
4.1.2. The most abundant fish species in the area is the Common Carp.

4.1.3. Most of the fishermen were between 20 up to 89 years. They generally used the fishing gear Panti or Kitig.

4.1.4. The daily income of the fisherman mostly ranged from 100 pesos to 1,500 pesos, The total income of the fisherman during the wet season is from 1,000 pesos to 10,000 pesos, and the daily expenses in each fishing trip is from 20 pesos to 100 pesos mostly used for the gasoline.As to the Cost Benefit Analysis, the average daily net net income of each fisherman is 281.27 pesos and the Return of Investment is $174.41 \%$.

4.2. Conclusions The conclusions of the study are as follows:

4.2.1. Among the fourteen collected fish species, the most abundant were Common Carp (Cyprinus carpio), Tilapia (Oreochromis niloticus), Hito (Hypostomus plecostomus)

4.2.2. There are a lot of fishing gears of the local fishermen like Bukatut, Kimput, Kuryenti, Mandali, Panti/Kitig, Screen, Skylab.

4.2.3. The income of the fishermen during wet season it is not enough according to the respondents. But based on the Cost Benefit Analysis and Return of Investment it is just enough on the Minimum wage of an individual.

4.2.4. The abundance affects the income of the fishermen depending to their daily catch if there are a lot of fish catch it will be enough for their daily needs.

4.3. Recommendations Based on the results gathered, the following recommendations are here forwarded:

4.3.1. Further studies to identify and classify fish species thriving in the unexplored areas of Candaba, Swamp shall be conducted.

4.3.2. Yearly survey on the population of fish species must be conducted to find out if new fish species are present in the other part of Candaba Swamp.

4.3.3. Fish inventory on the different sites should be conducted to know if there are different species on the other sites of Candaba Swamp.
4.3.4. Income of the local fishermen should be conducted During the Wet season and Dry Season for comparison.

Acknowledgement: To the Southeast Asian Regional Center for Graduate Study and Research in Agriculture (SEARCA) for the funding support and to the University of the Philippines School of Environmental Science and Management (UPLBSESAM).

Erratum: "Fish inventory and fishing practices of farmers in Candaba Swamp, Philippines: their implication to fishermen's income" Alfred D. Mallari, Jacqueline V. Bagunu, Gerald M. Salas. Scientific Journal of Tan Trao University, No. 15, March 2020; DOI: $\quad$ https://doi.org/10.51453/2354-1431/2020/350. Following publication of this paper, the journal was alerted that the authors and the acknowledgement of the published International Journal was incomplete and that it should include the author Gerald M. Salas as added accordingly and the acknowledgment as above.

\section{REFERENCES}

1. Bautista, M. \& Barila, J.V (2003), An inventory of the different species of Fishes in Candaba Swamo, Pampanga. BS Thesis, PAC, Magalang, Pampanga.

2. Kabigting, C. (2013), Heavy metal analysis on the gills female tilapia in selected areas of Candaba Swamp, Pampanga. BS Thesis, PAC, Magalang, Pampanga

3. Mallari, M. \& Bagunu, J.V. (2003), Taxonomy and Ecology of Molusks in Candaba Swamp, Candaba, Pampanga. BS Thesis, PAC, Magalang, Pampanga.

4. Melendres, R. (2014), The utilization of Candaba Swamp from prehistoric to present time: Evidences from Archaeology, History and Ethnography.

5. Torres, D. (2008), Interventions for wetland conservation in the Pampanga river basin and Candaba wetlands Philippines. 


\section{Bảng thống kê và tập quán đánh bắt cá ở đầm lầy Candaba, Philippines: ý nghĩa của chúng đối với thu nhập của ngư dân}

Alfred R. Mallari, Jacqueline V. Bagunu, Gerald M. Salas

\section{Thông tin bài viết}

Ngày nhận bài:

28/11/2019

Ngày duyệt đăng:

$10 / 3 / 2020$

Tù khoá:

Bảng thống kê cá;

Thực hành câu cá;

ngu cu; "Panti".

\section{Tóm tắt}

Nghiên cứu này nhằm mục đích tạo ra một kho cá ở đầm lầy Candaba và ghi lại các hoạt động đánh bắt của ngư dân địa phương vì chúng có liên quan đến thu nhập của họ. Nghiên cứu đã ghi nhận 14 loài cá khác nhau, mỗi loài đại diện cho 14 họ ở Barangays của San Agustin và Dukma Paralaya. Mười bốn loài là Elopshawaiensis, Glossobiusgiurus, Megalops cyprinoides, Cyprinuscarpio, Trichopodus pectoralis, Clariasbatrachus, Hypostomus plecostomus, Arius dispar, Hypophthalmichthys molitrix, Anabas testudineus, Carassiuscarasius, Labeorohita, Hypophthalmichthysnobilis, Oreochromis niloticus.

Bảng thống kê đã ghi nhận các loài cá rô phi, cá chép và cá Hito là những loài chiếm ưu thế nhất ở đầm lầy Candaba. Độ tuổi của ngư dân là từ 20 đến 89 , hầu hết trong số họ là từ 50-59, đã sử dụng các "panti” (kitig) làm ngư cụ và thu nhập hàng ngày từ 100 peso đến 1.500 peso. Tổng thu nhập của ngư dân trong mùa mưa là từ 1.000 peso đến 10.000 peso và chi phí hàng ngày trong mỗi chuyến đi câu là từ 20 peso đến 100 pê sô, chủ yếu được sử dụng cho xăng dầu.

Thu nhập của ngư dân phụ thuộc vào số lượng cá mà họ đánh bắt bị ảnh hưởng bởi những thay đổi trong mùa. Phân tích lợi ích chi phí cho thấy thu nhập ròng P281,27 mỗi ngày với tỷ lệ hoàn vốn đầu tư là 174,4\%. 